\title{
ANALISIS GENANGAN BANJIR AKIBAT LUAPAN BENGAWAN SOLO UNTUK MENDUKUNG PETA RISIKO BENCANA BANJIR DI KABUPATEN BOJONEGORO
}

\author{
Asep Sulaeman ${ }^{1}$, Ery Suhartanto ${ }^{2}$, Sumiadi $^{2}$ \\ ${ }^{1}$ Balai Litbang Sungai, Puslitbang Sumber Daya Air, Kementerian Pekerjaan Umum dan Perumahan Rakyat \\ ${ }^{2}$ Dosen Jurusan Teknik Pengairan, Universitas Brawijaya \\ Email: mangasepsule@yahoo.co.id, erysuhartanto@yahoo.com
}

\begin{abstract}
ABSTRAK: Jumlah kejadian banjir di kabupaten Bojonegoro sebanyak 105 kejadian dari kurun waktu 1815 sampai dengan 2016 (BNPB, 2016). Kejadian banjir di Bojonegoro umumnya diakibatkan oleh luapan Bengawan Solo. Penelitian ini dilakukan untuk menganalisi genangan banjir di Kabupaten Bojonegoro akibat terjadinya luapan air dari Bengawan Solo. Simulasi model genangan banjir dilakukan dengan model 1D/2D menggunakan software HEC RAS versi 5.03. Sedangkan untuk anali-sa daerah terdampak menggunakan ARC GIS 10. Hasil dari studi didapatkan bahwa luas genangan ha-sil simulasi pada masing-masing kala ulang di Kabupaten Bojonegoro adalah 250,33 km², untuk debit dengan kala ulang 100 tahun. Berturutturut luas genangan simulasi di Kabupaten Bojonegoro untuk debit kala ulang 50, 20, 10, 5, 2 tahun adalah 246,37 $\mathrm{km}^{2}, 240,62 \mathrm{~km}^{2}, 225,69 \mathrm{~km}^{2}, 169,23 \mathrm{~km}^{2}$, dan $126,48 \mathrm{~km}^{2}$. Tingkat ancaman banjir banjir di Kecamatan Kanor, Malo dan Trucuk memiliki tingkat ancaman tinggi dengan nilai lebih dari 0,7 pada debit kala ulang 2 tahun sampai 10 tahun. Tingkat ancaman pada daerah permukiman yang paling luas adalah di Kecamatan Bojonegoro.
\end{abstract}

Kata Kunci: Banjir, Genangan, HEC RAS 5, Tingkat ancaman banjir

ABSTRACT: The number of flood occurrences in Bojonegoro were 105 of the period 1815 to 2016 (BNPB, 2016). Flood in Bojonegoro is generally caused by the overflowing of Bengawan Solo River. This study was conducted to analyze the inundation in Bojonegoro due to the overflow of Bengawan Solo. Flood inundation model simulation performed by $1 D / 2 D$ model using HEC RAS ver. 5.03 software. Then for the analysis of affected areas using ARC GIS 10 software. The results of the study found that the vast inundation of simulation results for each return period in Bojonegoro is $250.33 \mathrm{~km}^{2}$, for return period of 100 years discharge. Extensive inundation simulation in Bojonegoro for each return period of 50, 20, 10, 5, 2 years discharges are 246,37 $\mathrm{km}^{2} 240,68 \mathrm{~km}^{2}, 22,69 \mathrm{~km}^{2}, 16,23 \mathrm{~km}^{2}$, and 12,48 $\mathrm{km}^{2}$. The flood hazard level in Kanor, Malo and Trucuk District have a high hazard with a value more than 0,7 on 2 years to 10 years discharges return period. The area which has the most extensive high hazard level is in Bojonegoro District.

Keywords: Flood, inundation, HEC RAS 5, Flood hazard

Bencana banjir di Indonesia merupakan bencana yang terus terjadi setiap tahun. Menurut catatan BNPB (2016) kejadian banjir dari tahun 1825 Sampai dengan November 2016 sebanyak 6915 kejadian yang merupakan $31,3 \%$ kejadian bencana di Indonesia. Bencana banjir selama kurun waktu itu mengakibatkan sekitar 2.798 orang meninggal serta sekitar 3.441.075 orang mengungsi. Pada rentang Januari-November 2016 terjadi kejadian 713 banjir yang mengakibatkan 2.555.750 orang mengungsi dan menderita serta 270.474 rumah teren-dam. Bencana banjir di provinsi Jawa Timur selama kurun waktu yang sama terjadi 929 kejadian, dengan 
jumlah kejadian banjir di kabupaten Bojonegoro sebanyak 105 kejadian.

Didalam EXIMAP (2007) pengelolaan bencana banjir yang efektif dan efisien memerlukan pengetahuan tentang bahaya dan risiko yang ada di daerah aliran sungai. Informasi bahaya dan risiko banjir yang dibutuhkan antara lain tipe banjir, kemungkinan kejadian banjir, luas genangan banjir, kedalaman dan kecepatan banjir, serta tingkat kerusakan (kehidupan, properti dan aktivitas ekonomi).

Salah satu metode untuk membantu pengelolaan banjir dilakukan dengan simulasi numerik. Simulasi numerik perkiraan banjir tidak dapat langsung mendapatkan hasil yang bagus karena genangan tergantung dari topografi dan itu berubah seiring waktu (Dinamik). Hal ini membuat prediksi banjir men-jadi lebih rumit dan memerlukan proses yang lama. Informasi banjir dengan tampilan visu-al membantu perencanaan lebih baik. Geographic Information System (GIS) dapat digunakan untuk menampilkan daerah banjir, dan juga digunakan untuk analisa peta genangan banjir untuk menghasilkan peta perkiraan kerusakan akibat banjir dan peta risiko banjir (Hausmann dan Webber, 1998; Clark, 1998 dalam Goel, dkk. 2005). Untuk memperkirkan genangan banjir dengan debit kala ulang, penggunaan GIS harus dikombinasikan dengan metode hidrologi/ hidraulika (Goel, dkk. 2005).

Bates (2004) didalam Alho (2009) menyebutkan bahwa model hidraulik yang dapat digunakan untuk pemetaan genangan banjir memerlukan empat tipe data masukan: (1) data topografi untuk membuat model geometri; (2) data debit aliran baik untuk memberi kondisi batas masukan atau keluaran; (2) estimasi parameter kekasaran efektif pada grid; (4) data untuk validasi. Sanders (2007) masih didalam Alho mengemukakan bahwa DEM dari sumber online di Amerika Serikat dan dites menggunakan model hidraulika 2D dengan jenis aliran steady dan unsteady dan menggunakan tinggi muka air, semakin data elevasi digital semakin kecil presisinya maka normalnya luas genangan yang dihasilkan semakin besar dan hasil terbaik dapat diperoleh dengan menggunakan LiDAR-DTM.

HEC-RAS versi 5.03 dapat diguna-kan untuk perhitungan hidraulik satu dimen-si, dua dimensi dan kombinasi 1 dimensi dan 2 dimensi. Dalam program $\mathrm{Hec}$ Ras dapat dilakukan aliran dengan aliran tetap (steady flow) dan aliran tidak tetap (unsteady flow).

Tujuan tulisan ini adalah untuk mengetahui luas dan kedalaman genangan banjir di Kabupaten Bojonegoro akibat lua-pan Bengawan Solo pada kejadian banjir dengan kala ulang 2, 5, 10, 20, 50 dan 100 tahunan dan mengetahui tingkat ancaman banjir di Kabupaten Bojonegoro yang terkena genangan banjir.

\section{BAHAN DAN METODE}

Bahan dan alat yang digunakan pada penelitian ini adalah Personal komputer, Software HEC-RAS 5.03, Software Arc GIS 10, Software Microsoft office Words dan Excell.

Pengumpulan data dilakukan secara sekunder yang meliputi data geometri sungai Bengawan Solo dari Karangnongko sampai Babat, yang bersumber dari BBWS Benga-wan Solo. Data topografi berupa Digital Elevation Model (DEM) dengan grid 30 x $30 \mathrm{~m}$, berumber data dari NASA SRTM. Data debit, sumber data dari BBWS Bengawan Solo dan Perum Jasa Tirta 1, Peta administrasi Kabupaten Bojonegoro, sumber data dari BIG (Badan Informasi Geografis).

Pembuatan peta genangan banjir dilakukan dengan pendekatan hidraulika digabungkan dengan DEM untuk membatasi daerah yang terdampak banjir. Perhitungan hidraulika dilakukan dengan menggunakan data debit yang tercatat pada pos duga muka air di Pos Karangnongko, Bojonegoro dan Babat. Pembuaatan peta ancaman banjir dilakukan dengan melakukan simulasi numerik banjir 1 dimensi/2 dimensi (1D/2D) dengan bantuan software HEC-RAS versi 5.03.

Untuk memprediksi besaran luasan genangan banjir dilakukan pada debit kala ulang 2, 5, 10, 20, 50 dan 100 tahunan. Penentuan debit rancangan pada boundary hulu dilakukan dengan menggunakan data debit di stasiun pengamatan muka air Karangnongko, yang dihitung dengan menggunakan analisa frekuensi distribusi Gumbel, dengan analisis kesesuaian Chi kuadrat dan Smirnov-Kolmogorov. Debit rancangan yang didapatkan kemudian dikonversi menjadi hidrograf dengan 
pendekatan distribusi hidrograf hasil pengamatan debit jam-jaman pada kejadian banjir 25 Desember 2007 sampai dengan 3 Januari 2008.

Hasil dari peta genangan diubah menjadi tingkat ancaman banjir secara spasial

Tabel 1. Indeks ancaman bencana banjir

\begin{tabular}{ccccc}
\hline Kedalaman & Kelas & Nilai & $\begin{array}{c}\text { Bobot } \\
(\boldsymbol{\%})\end{array}$ & Skor \\
\hline$<0.76$ & Rendah & 1 & & 0,333 \\
$0,76-1,5$ & Sedang & 2 & 100 & 0,667 \\
$>1,5$ & Tinggi & 3 & & 1,000 \\
\hline Sumber: $B N P B(2012)$ & & &
\end{tabular}

Kalibrasi hasil simulasi genangan dilakukan dengan membandingkan tinggi muka air hasil pengaliran dengan tinggi muka air di lapangan pada pos-pos pencatat tinggi muka air seperti Pos Karangnongko, Pos Bojonegoro dan Pos Babat seperti terlihat pada Gambar 1.

Untuk kalibrasi fenomena keluar masuk aliran dianalisis juga kesamaan model dalam mengalirkan debit di boundary hilir yaitu dipos Babat.

Dilakukan juga pembandingan pembandingan antara daerah genangan hasil simulasi dengan daerah genangan hasil pencatatan genangan banjir yang terjadi.

Kalibrasi dan evaluasi model hidrologi dengan data hasil pengukuran dilakukan dengan menggunaka Nash-Sutcliffe efficiency (NSE). Indeks relatif Nash Sutcliffe dapat digunakan sebagai perbandingan kinerja model antara periode atau DAS. NSE didefinisikan sebagai proporsi varians awal dengan membagi jumlah kuadrat errors (F) oleh varian awal (Fo) yang dapat dilihat pada persamaan 1, 2 dan 3.

$F=\sum_{i=1}^{n}\left(Q_{o b s_{i}}-Q_{s i m_{i}}\right)^{2}$

$F o=\sum_{i=1}^{n}\left(Q_{o b s i}-\overline{Q_{o b s}}\right)^{2}$

$E=1-\frac{F}{F_{0}}$

dengan:

E : nilai NSE

Qobs i : nilai pengukuran ke-i dengan perangkat lunak Arc GIS 10. Kategori tingkat ancaman berdasarkan Peraturan Kepala Badan Nasional Penanggu-langan Bencana (BNPB) No.2 Tahun 2012 tentang Pedoman Umum Pengkajian Risiko Bencana, seperti terlihat pada tabel 1 .

Tabel 2. Tingkat kinerja NSE

\begin{tabular}{ll}
\hline Nash Sutcliffe & Tingkat kinerja \\
\hline $0,75<\mathrm{NSE}<1.00$ & Sangat Bagus \\
$0,65<\mathrm{NSE}<0,75$ & Bagus \\
$0,50<\mathrm{NSE}<0,65$ & Memuaskan \\
$<0,50$ & Tidak memuaskan \\
\hline
\end{tabular}

Sumber: SJRWMD

Qsim i : nilai simulasi ke-i

$\overline{Q_{o b s}} \quad$ : rata-rata nilai pengukuran

Nilai NSE 1 mengindikasikan kesesuaian yang sempurna dan nilai 0 mengindikasikan bahwa model tidak menggambarkan bagian apapun dari varians awal (Mathevet dkk, 2006).

Dari SJRWMD (2016) disebutkan tingkat kinerja untuk koefesien efesiensi NashSutcliffe ditampilkan pada tabel 2.

Untuk menununjukan seberapa besar varian antara dua variabel digambarkan dengan kesesuaian linear.

kesesuaian linear ini digunakan koefesien korelasi Pearson kuadrat $\left(\mathrm{r}^{2}\right)$ yang biasa disebut juga koefesien determinasi. Koefesien korelasi Perason kuadrat antara model dan pengukuran digunkana dengan persamaan 4 .

$$
r^{2}=\left(\frac{\sum_{i=1}^{n}\left(x_{i}-\bar{x}\right) \cdot\left(y_{i}-\bar{y}\right)}{\sqrt{\sum_{i=1}^{n}\left(x_{i}-\bar{x}\right)^{2} \cdot \sum_{i=1}^{n}\left(y_{i}-\bar{y}\right)^{2}}}\right)^{2}
$$

Korelasi +1 terjadi pada hubungan sempurna linear meningkat, dan -1 terjadi pada hubungan linear menurun, serta nilai diantaranya mengindikasikan tingkat hubungan linear antara hasil model dengan pengukuran. koefesien korelasi 0 berarti tidak ada hubungan linear antara variabel.

Nilai kesesuaian perbandingan antara area genangan hasil simulasi dengan hasil pengukuran menurut beberapa peneliti seperti Bates dan De Roo (2000), Aronica, dkk (2002), Horritt (2006) dan Nadalal (2011) 
dalam Silva (2012), Sarhadi dkk (2012), Ali dkk (2015), dan Silva (2016) menggunakan persamaan 5 .

$F(\%)=\frac{\text { Sobs } \cap \text { Smod }}{\text { Sobs U Smod }} \times 100$

Dimana Sobs dan Smod adalah luasan genangan hasil pengukuran lapangan dan luas genangan hasil simulasi model serta $\mathrm{F}$ adalah nilai kesesuaian model.

Apabila overlay area genangan hasil simulasi sama persis dengan area genangan hasil pengukuran, maka nilai kesesuiannya 100 $\%$ (Silva, 2016)

Sebagai pambanding dilakukan juga penilaian kesesuaian genangan hasil simulasi dan pengukuran lapangan dengan metode dari Di Baldassarre (2009), yang dilakukan dengan menggunakan persamaan 6 .

$F=\frac{A-B}{A+B+C}$

A menunjukan luas area genangan yang benar, antara model dan pengukuran sama-sama tergenang. B menunjukan kesalahan model yang mengakibatkan prediksinya berlebihan, hasil model menyatakan terg-nang tetapi hasil pengukuran lapangan tidak tergenang. $\mathrm{C}$ menunjukan ada daerah gena-ngan yang tidak ditunjukan oleh model sehingga prediksinya kurang, dengan hasil model menyatakan tidak tergenang tetapi hasil pengukuran menyatakan tergenang.

Nilai kesesuaian berkisar antara 0 sampai 1. Nilai kesesuaian mendekati 0 mengindikasikan hasil overlay yang jelek antara simulasi dan pengukuran.

Lokasi kajian berada di Wilayah Sub DAS Bengawan Solo Hilir dengan luas 6.273 $\mathrm{km}^{2}$, dengan analisa genangan banjir dilakukan pada segmen Karangnongko - Babat seperti terlihat pada Gambar 1.

Panjang sungai antara KarangnongkoBabat 153,164 km dan analisa dampak genangan dikhususkan di Kabupaten Bojonegoro, Jawa Timur.

\section{HASIL DAN PEMBAHASAN}

Pemodelan genangan banjir Bengawan Solo dibangun dengan memasukan unsur geometri sungai, Digital Elevation Model (DEM) dataran banjir dan input data debit. Pada simulasi banjir tahun 2007 geometri sungai menggunakan geometri hasil pengukuran tahun 2007 sebelum kejadian banjir untuk segmen Cepu-Babat, disambungkan dengan geometri hasil pengukuran tahun 2010 dari Balai Sungai sepanjang 153,164 km.

DEM yang digunakan adalah DEM SRTM grid $30 \mathrm{~m}$ yang didownload dari USGS di website https://earthexplorer.usgs.-gov/. Input debit merupakan debit pengukuran di Pos Karangnongko dan Bojonegoro.

Elevasi dasar sungai di Karangnongko berada pada $+22,461 \mathrm{~m}$ dan elevasi dasar sungai di Babat pada elevasi $-4,72 \mathrm{~m}$. Kemiringan rata-rata apabila ditinjau menjadi dua segmen kemiringan dengan pembagian berdasarkan letak pos duga muka air maka didapatkan kemiringan dasar sungai Karangnongko - Bojonegoro sebesar 0,0002 dan kemiringan dasar sungai segmen Bojonegoro Babat sebesar 0,0001. Potongan melintang sungai yang digunakan mempunyai lebar sungai bervariasi dengan lebar rerata sekitar $200 \mathrm{~m}$.

Debit sungai untuk kalibrasi model genangan banjir digunakan hidrograf debit di lokasi pos duga muka air Karangnongko, Bojonegoro dan Babat pada tanggal 25 Desember 2007 - 03 Januari 2008. Masingmasing hidrograf dapat dilihat pada gambar 2.

Debit maksimum di pos Karangnongko sebesar $2091 \mathrm{~m}^{3} / \mathrm{dt}$, debit maksimum di pos Bojonegoro sebesar 2508 $\mathrm{m}^{3} / \mathrm{dt}$ dan debit maksimum di pos Babat sebesar $1886 \mathrm{~m}^{3} / \mathrm{dt}$. Debit yang terjadi di Bojonegoro apabila kala ulangnya dihitung berdasarkan distribusi Gumbel adalah debit kala ulang 8,4 tahun

Debit input di Boundary hulu Pos Karangnongko dan di Pos Bojonegoro digunakan hasil analisis distribusi Gumbel yang dapat dilihat pada Tabel 3. 


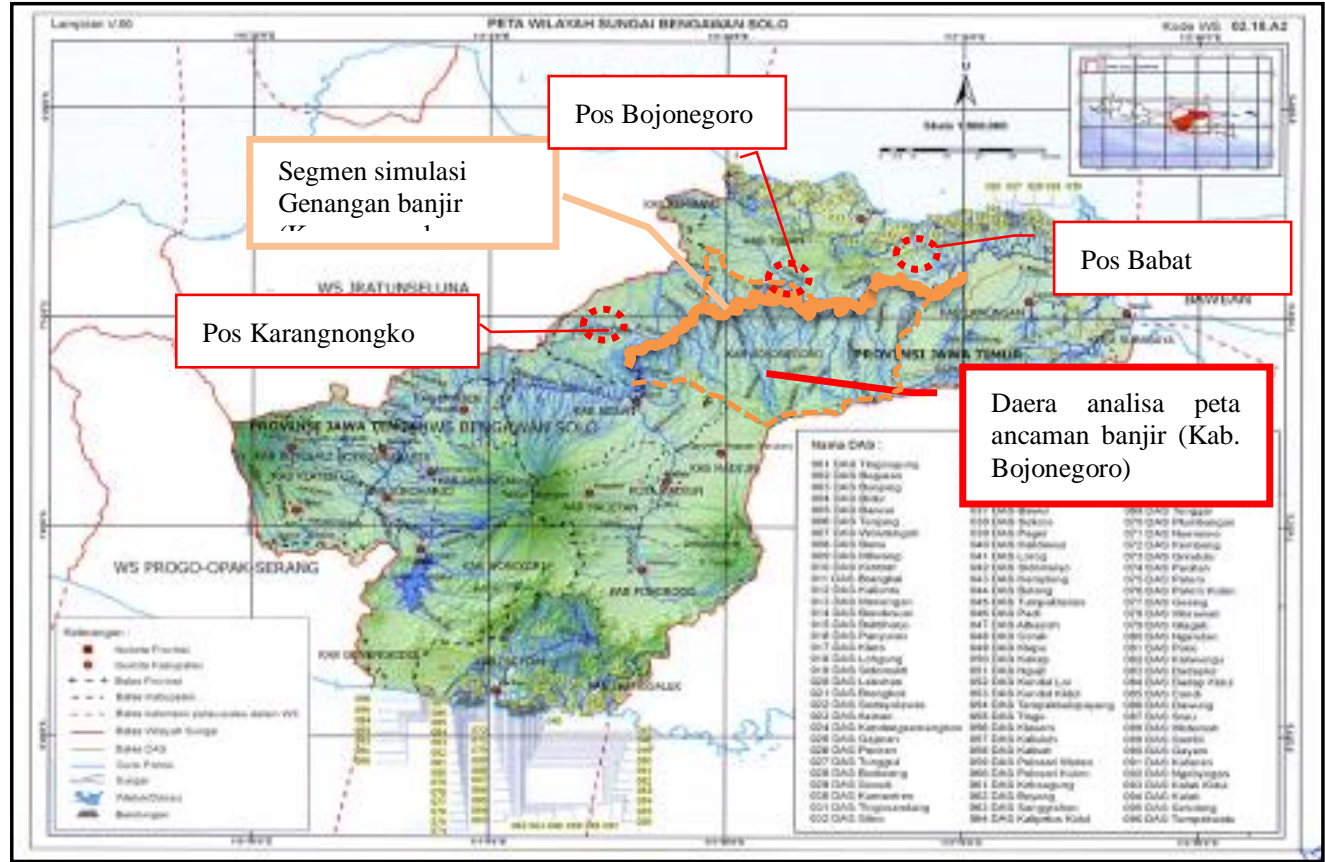

Gambar 1. Lokasi kajian peta resiko bencana banjir

Sumber: Kepres No 12 Tahun 2012. Tentang Penetapan Wilayah Sungai

Distribusi yang menampilkan hidrograf di Pos Karang-nongko untuk tiap kala ulang banjir dan Gambar 5 yang menampilkan hidrogaf di Pos Bojonegoro tiap kala ulang banjir.

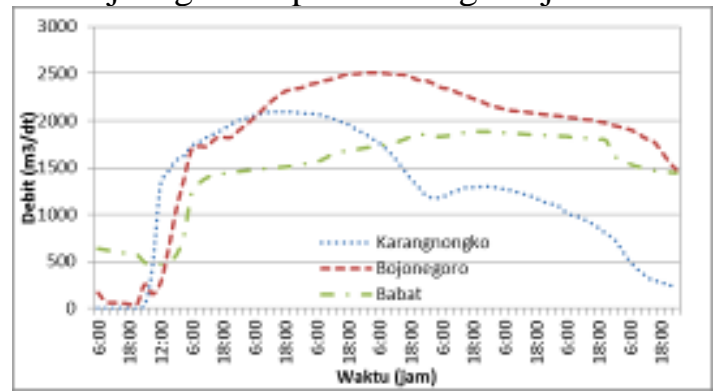

Gambar 2. Hidrograf banjir Bengawan Solo kejadian Desember 2007

Sumber: BBWS Bengawan Solo

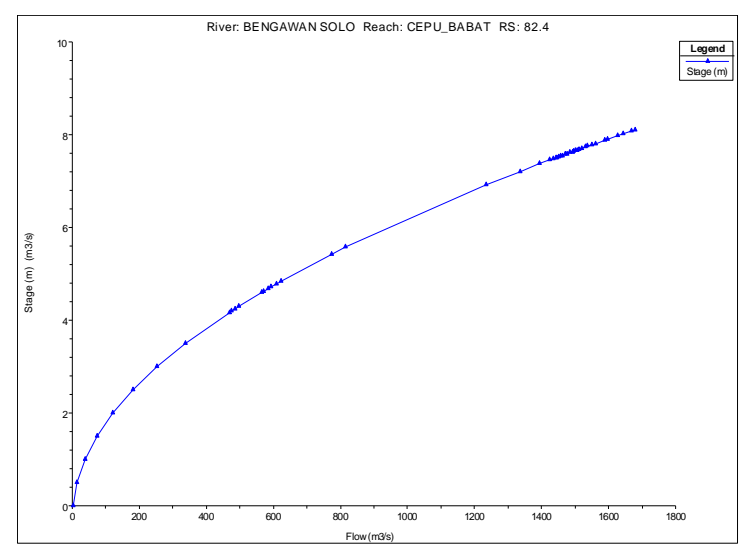

Gambar 3. Rating curve pos Babat Sumber: BBWS Bengawan Solo
DEM SRTM Bengawan Solo hilir yang digunakan mepunyai perbedaan elevasi yang signifikan dengan elevasi hasil pengukuran geometri sungai. Perbandingan beberapa titik menunjukan rata-rata elevasi DEM lebih tinggi 5,06 $\mathrm{m}$ dibanding hasil pengukuran. Untuk menggabungkan antara DEM SRTM bantaran banjir dan DEM alur sungai hasil pengukuran dilakukan penurun elevasi DEM secara seragam terlebih dahulu.

Hal ini dilakukan juga sebagai pendekatan untuk mengakomodir proses aliran genangan model simulasi. Peta daerah genangan banjir yang digunakan sebagai dasar perbandingan model adalah peta genangan banjir pada 28 Desember 2007 dari Balai Besar Wilayah Sungai Bengawan Solo.

Peta tersebut dilengkapi dengan informasi daerah genangan dari BPBD Bojonegoro dan juga wawancara dengan warga lokal. Daerah Kabupaten Bojonegoro yang tekena dampak banjir terdiri dari 15 kecamatan yang meliputi 127 Desa di sekitar Bengawan Solo dengan luas genangan sesuai batas model adalah $414,71 \mathrm{~km}^{2}$. 
Tabel 3. Distribusi Gumbel debit tahunan maksimum

\begin{tabular}{cccc}
\hline No. & $\begin{array}{c}\text { Periode Ulang } \\
\operatorname{Tr} \text { (tahun) }\end{array}$ & $\begin{array}{c}\text { Debit di } \\
\text { Karangnongko } \\
\text { Qt } \quad\left(\mathrm{m}^{3} / \mathrm{dt}\right)\end{array}$ & $\begin{array}{c}\text { Debit di } \\
\text { Bojonegoro } \\
\text { Qt } \\
\left(\mathrm{m}^{3} / \mathrm{dt}\right)\end{array}$ \\
\hline 1 & 2 & 1333 & 1883 \\
2 & 5 & 1642 & 2316 \\
3 & 10 & 1847 & 2602 \\
4 & 20 & 2050 & 2877 \\
5 & 50 & 2299 & 3237 \\
6 & 100 & 2488 & 3502 \\
\hline
\end{tabular}

Sumber: Hasil Perhitungan (2016)

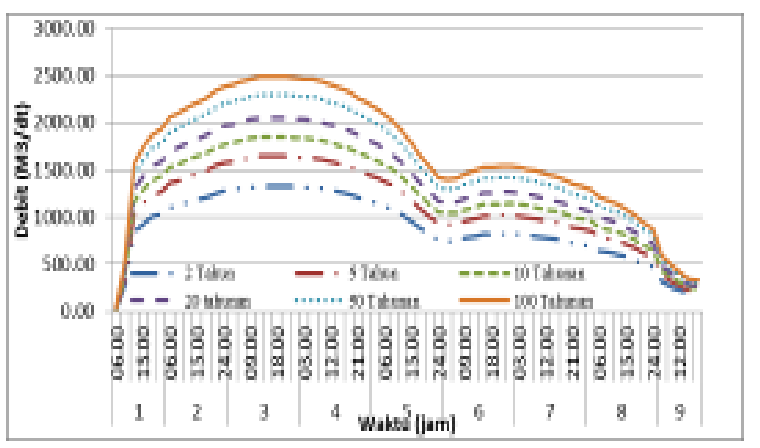

Gambar 4. Hidrogaf Banjir Rencana di Stasiun Karangnongko

Sumber: Hasil Perhitungan (2016)

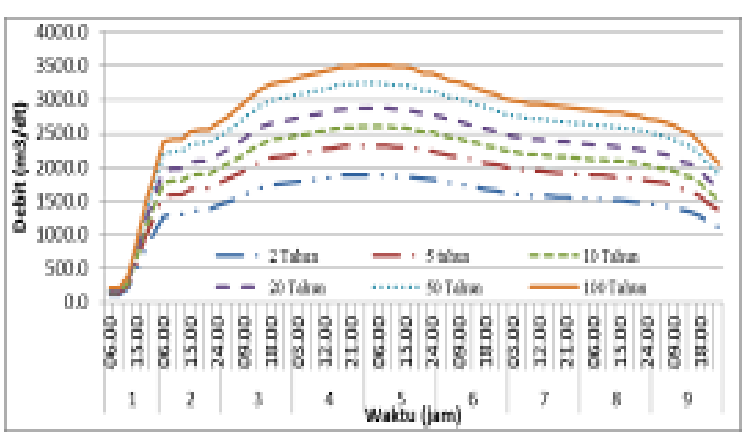

Gambar 5. Hidrogaf Banjir Rencana di Stasiun Bojonegoro

Sumber: Hasil Perhitungan (2016)

Genangan banjir hasil simulasi akibat debit di hulu $2091 \mathrm{~m}^{3} / \mathrm{dt}$ dan adanya tambahan debit di Bojonegoro sehingga debit yang tercatat di pos pengamatan sebesar $2535 \mathrm{~m}^{3} / \mathrm{dt}$ mengakibatkan genangan banjir seluas 369,10 $\mathrm{km}^{2}$ pada luasan yang dimodelkan dan kedalaman genangan bervariasi sampai dengan $4 \mathrm{~m}$ yang dapat dilihat pada Gambar 6. Hasil kalibrasi debit di pos Babat dengan menggunakan Efisiensi Nash Sutchliffe didapat nilai $\mathrm{E}=0,92$.

Nilai tersebut termasuk kriteria sang-at bagus menurut kriteria SJRWMD pada Ta-bel
2. Hasil perhitungan nilai koefesien korelasi Pearson kuadrat $\left(r^{2}\right)$ menunjukan juga hubungan yang sangat bagus antara model dan pengukuran dengan didapatkan nilai 0,95 . Perbedaan nilai antara simulasi dan model dapat dilihat pada Gambar 7.a Pada gambar 7.a tampak bahwa debit kecil perbedaannya cukup besar, sedangkan pada debit besar nilai hasil simulasi dan pengkuran dekat kepada garis $45^{\circ}$.

Dari Gambar 7.b dapat dilihat bahwa trend hidrografnya tidak terlalu sama. Tren naik setelah debit mencapai $1400 \mathrm{~m}^{3} / \mathrm{dt}$ menjadi melandai dan setelah mencapai debit $1500 \mathrm{~m}^{3} / \mathrm{dt}$ grafik naik dengan cepat mendekat ke garis hasil pengamatan di lapangan.

Hasil Kalibrasi tinggi muka air (TMA) di pos Karangnongko dengan nilai efisiensi Nash-Sutcliffe didapatkan nilai 0,96 . Nilai ini masuk dalam kategori sangat bagus menurut Tabel 2 dari SJRWMD.

Perhitungan korelasi Pearson kuadrat didapat nilai 0,98 . Hal ini berarti 98\% TMA nilai simulasi mampu menjelaskan TMA hasil pengukuran. Kesesuaian antara model dan pengukuran yang sangat bagus terjadi pada TMA yang tinggi diatas $28 \mathrm{~m}$.

Mengingat banjir terjadi pada kondisi debit besar maka kesesuaian yang sangat bagus pada TMA elevasi yang tinggi sangat cocok untuk model. Nilai perbedaan antara hasil simulasi dengan pengukuran dapat dilihat pada gambar 8.a, tampak bahwa nilai yang berimpit dengan garis $45^{\circ}$ berada pada TMA besar diatas $28 \mathrm{~m}$.

Perbandingan tren TMA dapat dilihat pada Gambar 8.b Dari perbandingan TMA tersebut tampak bahwa baik tren maupun nilai TMA mempunyai kemiripan yang tinggi. TMA maksimum hasil pengukuran $31,80 \mathrm{~m}$ sedangkan TMA hasil simulasi sebesar 31,89 $\mathrm{m}$.

Untuk perbandingan genangan banjir didasarkan pada luas dan sebarannya. Luas genangan banjir hasil simulasi adalah 369,104 $\mathrm{km}^{2}$. Sedangkan luas genangan hasil pengukuran sebesar 414,706 $\mathrm{km}^{2}$. Luas genangan yang sama antara hasil model dan pengukuran Smod $\cap$ Sobs sebesar 320,654 km atau sebesar $77,32 \%$.

Daerah dengan luas $48,754 \mathrm{~km}^{2}$ dinyatakan simulasi sebagai area tergenang padahal berdasarakan catatan pengukuran merupakan daerah yang kering. Daerah hasil 
simulasi dinyatakan kering padahal hasil pengukuran merupakan daerah yang tergenang seluas 98,349 $\mathrm{km}^{2}$. Luas gabungan antara model dan pengukuran (Smod U Sobs) adalah $453,434 \mathrm{~km}^{2}$.

Dengan menggunakan persamaan 5 dari Bates, didapatkan nilai kesesuaian model dan pengukuran lapangan $F=70,72 \%$. Nilai kesesuaian luas genangan hasil simulasi model sebesar 70,72 \% termasuk dalam kriteria bagus. Nilai ini juga tidak jauh berbeda apabila dibandingkan dengan hasil penelitian yang dilakukan sebelumnya yang meng-gunakan DEM dengan akurasi yang lebih baik.

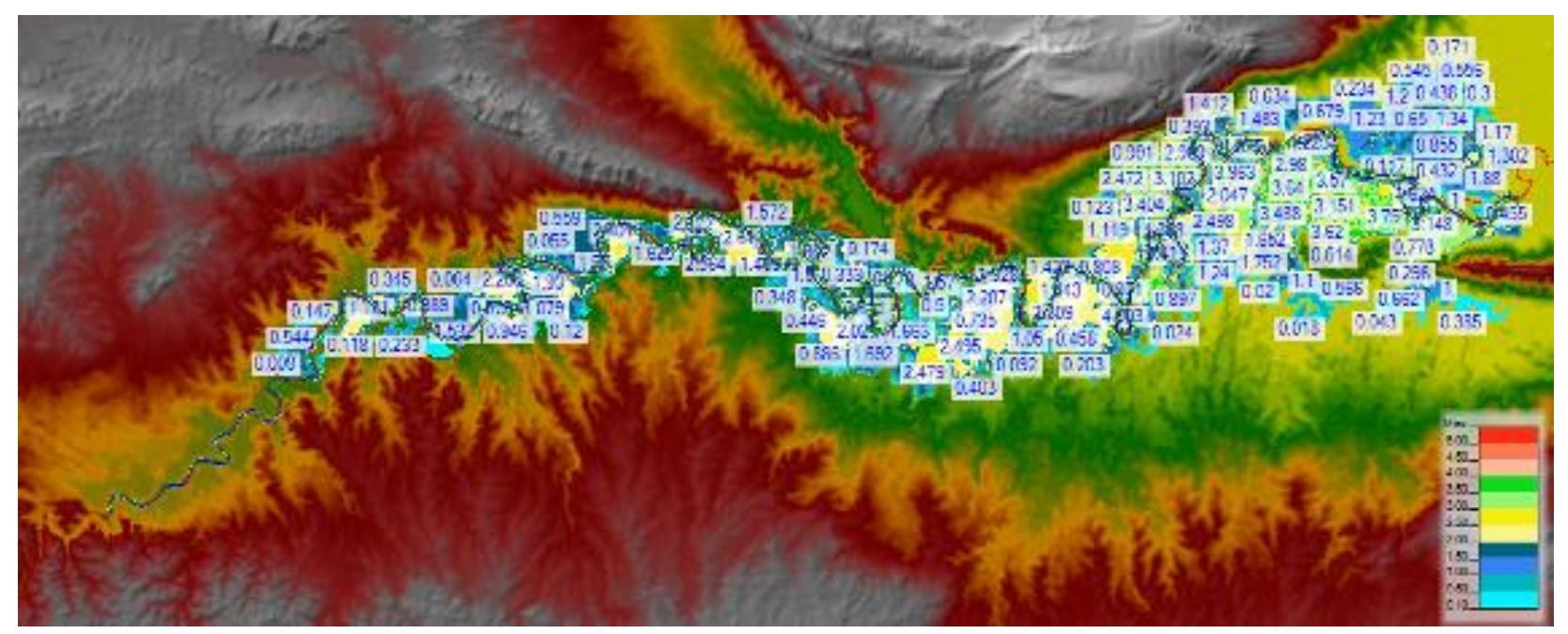

Gambar 6. Nilai kedalaman maksimum genangan banjir Desember 2007 hasil simulasi.

Sumber: Hasil Analisis (2016)

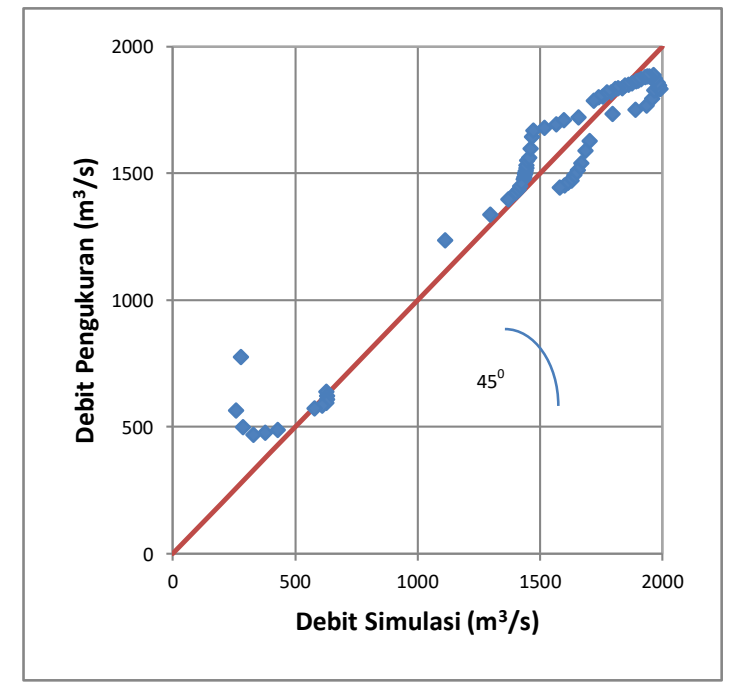

(a)

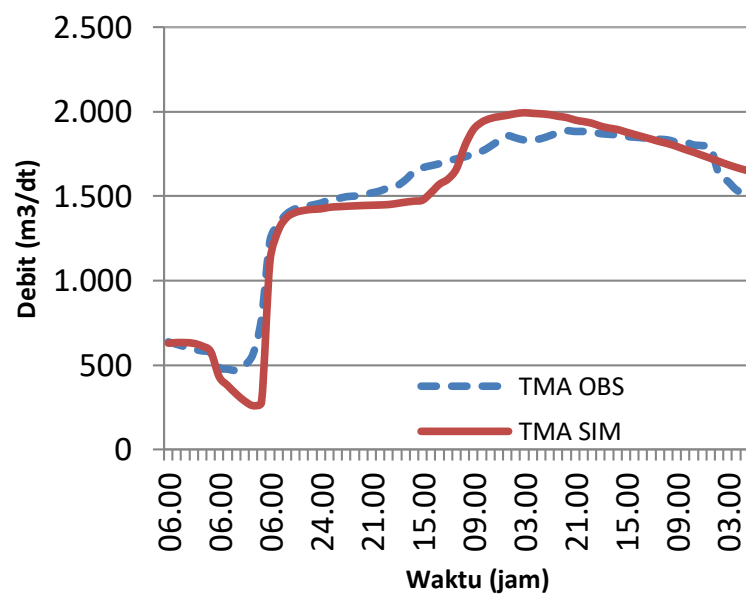

(b)

Gambar 7. a. Grafik kesesuaian debit hasil simulasi dan pengukuran di pos Babat

b. Hidrograf debit hasil simulasi dan pengukuran di pos Babat

Sumber: Hasil Perhitungan (2016) 


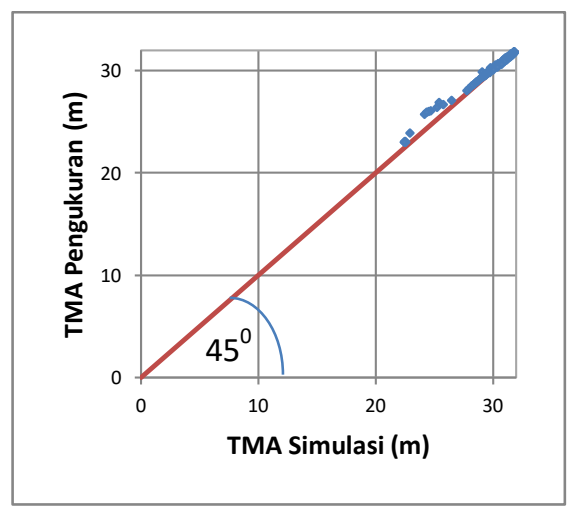

(a)

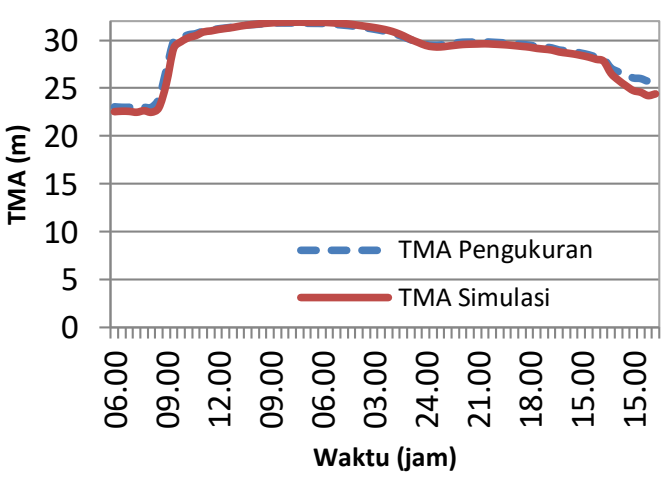

(b)

Gambar 8. a. Grafik kesesuaian TMA hasil simulasi dan pengukuran di pos Karangnongko

b. Hydrograf TMA hasil simulasi dan pengukuran di pos Karangnongko

Sumber: Hasil Perhitungan (2016)

Dari penelitian De Silva, dkk (2012) dengan menggunakan persaamaan yang sama didapatkan nilai kesesuaian model F $79 \%$ dan 73\%. Sedangkan Bates dan De Roo (2000) dalam hasil penelitiannya menyatakan bahwa nilai kesesuaian dan persentase kebenaran luas genengan model untuk DEM $25 \mathrm{~m}, 50 \mathrm{~m}$ dan $100 \mathrm{~m}$ adalah $80 \%$ dan $83 \%$, 64\% dan $69 \%$, $63 \%$ dan $69 \%$, 63\% dan 69\%. Nilai kesesuaian dipengaruhi oleh luas genangan yang dimodelkan, serta peta yang menjadi acuan pembanding model.

Hasil simulasi genangan pada masingmasing debit rencana dapat dilihat pada Tabel 4. Setiap kenaikan debit kala ulang menjadikan luasan terdampak genangan banjir semakin besar. Luas genangan dengan kala ulang 100 tahun sebesar 418,418 $\mathrm{km}^{2}$ untuk luasan genangan model keseluruhan sedangkan luas genangan model di Kabupaten Bojonegoro adalah $250,326 \mathrm{~km}^{2}$. Luas genangan untuk kala ulang 2 tahun adalah $213,323 \mathrm{~km}^{2}$, untuk luasan genangan model keseluruhan sedangkan luas genangan model di Kabupaten Bojonegoro adalah 126,476 km².

Tabel 5 memperlihatkan kesesuaian genangan model dengan genangan hasil pengukuran. Nilai kesesuaian (F) model yang paling tinggi adalah simulasi dengan debit kejadian banjir tahun 2007 dengan nilai 0,71 apabila menggunakan metode dari Bates, dkk sedangkan metode Di Baldassare didapatkan nilai $\mathrm{F}$ sebesar 0,58. Meskipun secara rasio perbandingan langsung, luas genangan yang sama-sama tergenang antara model dan pengukuran paling mendekati adalah model dengan debit kala ulang 100 tahun sebesar $82,8 \%$.

Nilai kesesuaian tersebut dipeng-aruhi oleh luasan model genangan yang berlebih (over estimate) dan luasan model yang diangggap kering (under estimate), dan pada metode Di Baldassarre nilai over-estimate digunakan sebagai pengurang nilai luasan yang dianggap benar. Selain itu model simulasi ini dibangun dengan meng-gunakan DEM yang cukup kasar akurasi vertikalnya. Selain itu luasan genangan hasil pengukuran yang digunakan sebagai dasar perbandingan tidak cukup akurat yang didapatkan dari hasil penggabungan beberapa data. Peta genangan hasil pengukuran juga diturunkan dari data batas wilayah desa sebagai batas genangan, hal ini berbeda dengan batas genangan hasil simulasi model yang berdasarkan kontur.

Jumlah desa tergenang untuk tiap kecamatan dan luas genangan pada kala ulang 2 tahun di Kecamatan Baureno mengalami desa terdampak paling banyak, dan daerah yang paling luas terkena dampak genangan dengan luas $35,159 \mathrm{~km}^{2}$ atau sebanyak $52,97 \%$ dari luas Kecamatan Baureno. Pada kala ulang 5 tahun Kecamatan Baureno paling banyak mendapatkan desa terdampak banjir dengan 25 desa, dan luas genangan sebesar $38,982 \mathrm{~km}^{2}$ atau seluas $58,73 \%$ dari luas kecamatan Baureno. Pada kala ulang 10 tahun Kecamatan kanor sebagai daerah yang paling luas terkena dampak genangan dengan luas $41,698 \mathrm{~km}^{2}$. Luas tersebut merupakan $69,75 \%$ luas Kecamatan Kanor. Pada kala ulang 20, 50 dan 100 tahun Kecamatan Kanor juga sebagai kecamatan yang paling luas terdampak dengan 
$44,889 \mathrm{~km}^{2}(75,09 \%), 44,809 \mathrm{~km}^{2}(74,96 \%)$ dan $45,244 \mathrm{~km}^{2}(75,68 \%)$, yang berdampak pada 24 desa.

Tingkat ancaman berdasarkan nilai kedalaman banjir memperlihatkan bahwa Kecamatan Kanor, Malo dan Trucuk memiliki tingkat ancaman tinggi dengan nilai lebih dari 0,7 pada debit kala ulang 2 tahun. Pada debit kala ulang 5 tahun kecamatan yang memiliki tingkat ancaman tinggi adalah Kecamatan Balen, Baureno, Bojonegoro, Kanor, Kapas. Pada debit kala ulang 10 tahun, Kecamatan yang memiliki tingkat ancaman tinggi adalah
Kecamatan Balen, Baureno, Bojonegoro, Dander, Kalitidu, Kanor, Kapas, Kasiman, Malo dan Trucuk. Pada debit dengan kala ulang 20 tahun, Kecamatan yang memiliki tingkat ancaman tinggi adalah Kecamatan Balen, Baureno, Bojonegoro, Dander, Kalitidu, Kanor, Kapas, Kasiman, Malo, Padangan, Sumberejo dan Trucuk. Pada debit dengan kala ulang 50 tahun, kecamatan yang memilki tingkat ancaman tinggi adalah Kecamatan Balen, Baureno, Bojonegoro, Dander, Kalitidu, Kanor, Kapas, Kasiman, Malo, Padangan, Sumberejo dan Trucuk. Pada debit dengan

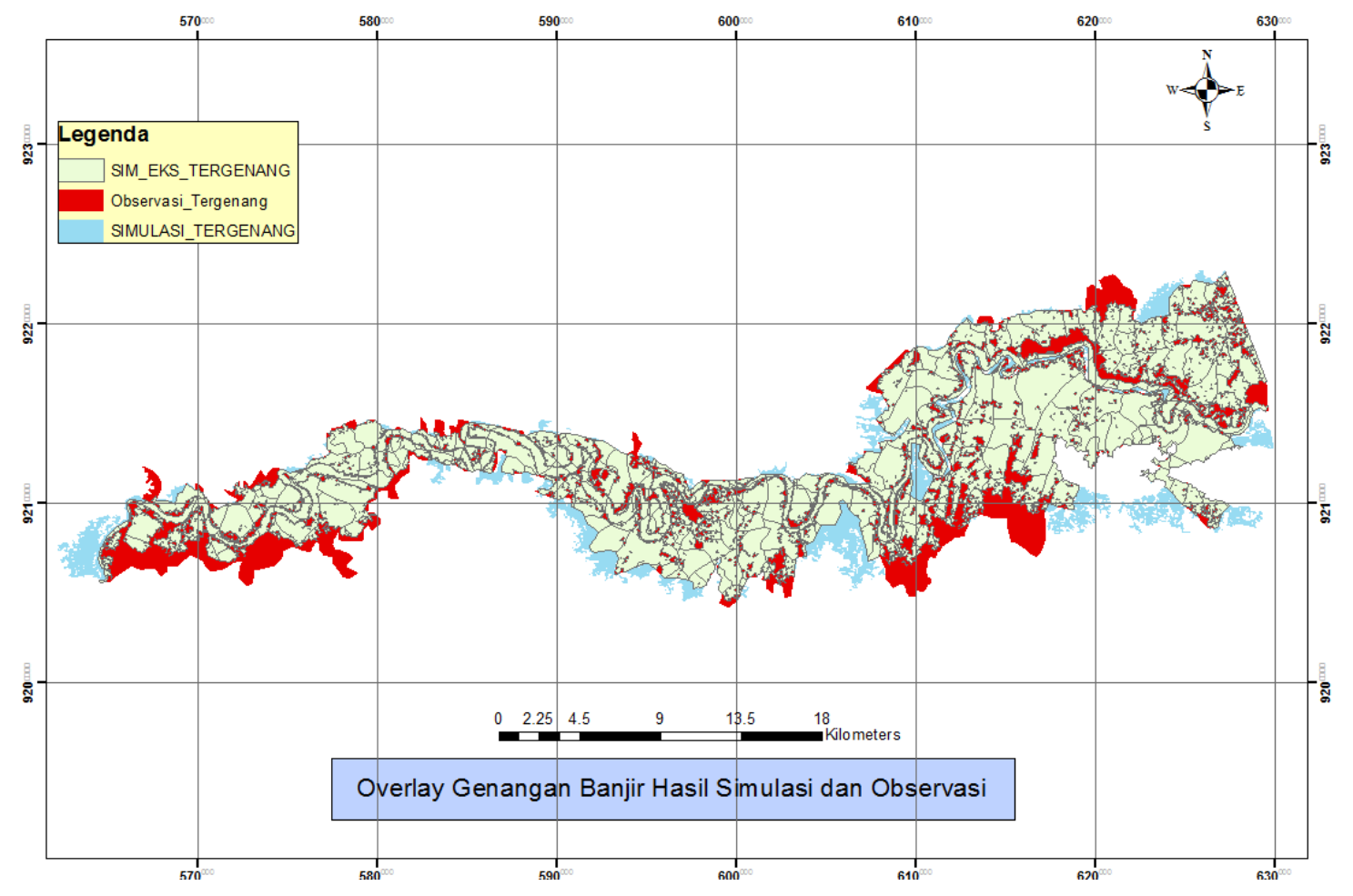

Gambar 9. Peta overlay genangan banjir hasil simulasi dan pengukuran kejadian Desember 2007 Sumber: Hasil Analisis (2016)

kala ulang 100 tahun, Kecamatan yang memilki tingkat ancaman tinggi adalah Kecamatan Balen, Baureno, Bojonegoro, Dander, Kalitidu, Kanor, Kapas, Kasiman,
Malo, Padangan, Sumberejo dan Trucuk. Sebarang tingkata ancaman banjir dapat dilihat pada Gambar 10.

Tabel 4. Luas genangan banjir di Kabupaten Bojonegoro pada berbagai debit kala ulang

\begin{tabular}{lcccccc}
\hline & \multicolumn{6}{c}{ Luas $\left(\mathbf{k m}^{2}\right)$} \\
\cline { 2 - 7 } & Q2 & Q5 & Q10 & Q20 & Q50 & Q100 \\
\hline $\begin{array}{l}\text { Luas simulasi model } \\
\begin{array}{l}\text { Luas simulasi di } \\
\text { bojonegoro }\end{array}\end{array}$ & 213.3229 & 293.9439 & 372.6033 & 405.7543 & 412.7546 & 418.4180 \\
$\begin{array}{l}\text { Persentase terhadap luas } \\
\text { Kab. Bojonegoro }\end{array}$ & 126.4757 & 169.2282 & 225.6909 & 240.6218 & 246.3696 & 250.3260 \\
\hline
\end{tabular}

Sumber: Hasil Perhitungan (2016) 
Tabel 5. Nilai kesesuaian model simulasi tehadap catatan genangan banjir

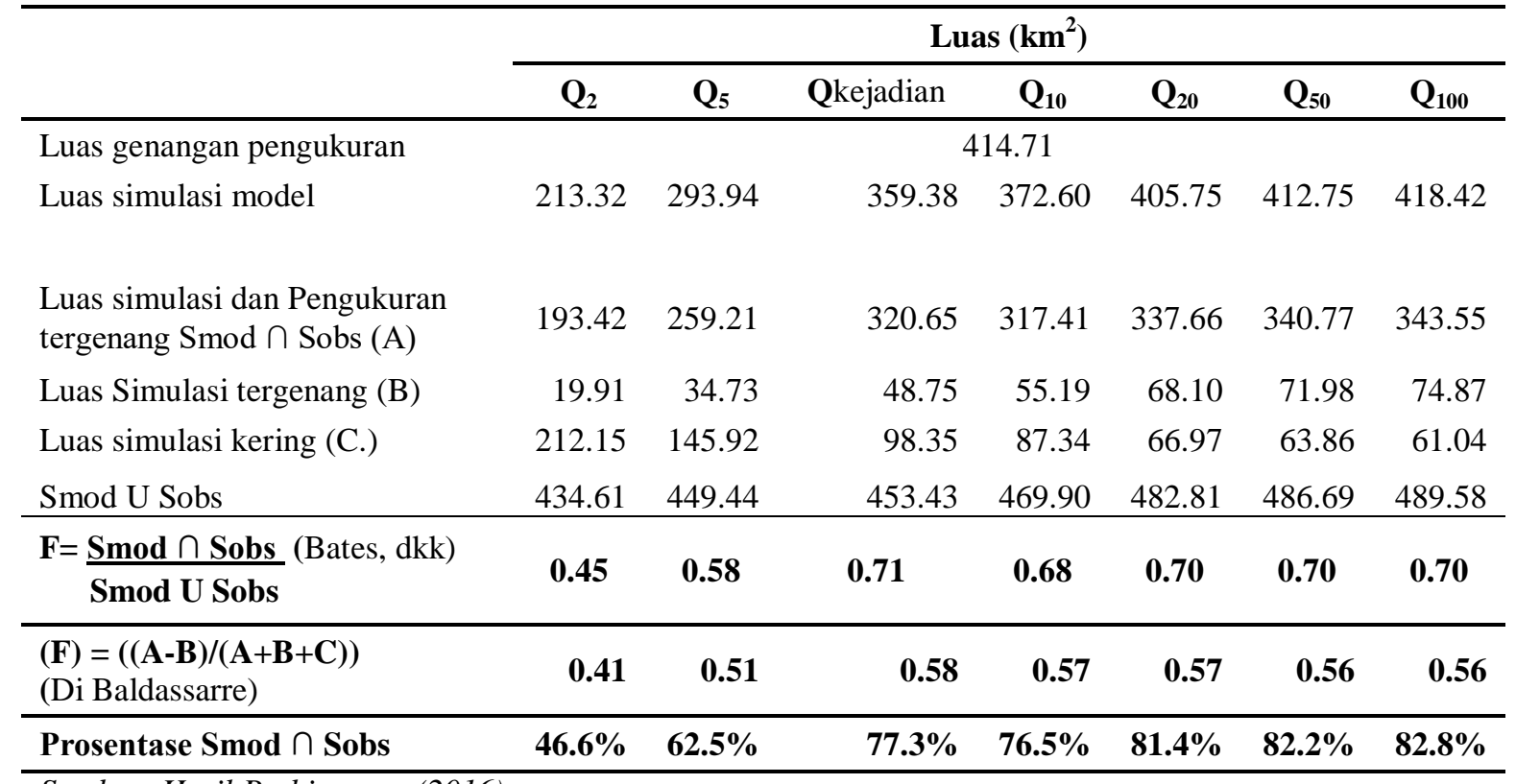

Sumber: Hasil Perhitungan (2016)

Tabel 6. Rekapitulasi tata guna lahan terdampak genangan banjir hasil simulasi di Kabupaten Bojonegoro

\begin{tabular}{lrrrrrr}
\hline \multirow{2}{*}{ Tata guna lahan } & $\begin{array}{c}\text { Luas } \\
\left(\mathbf{k m}^{2}\right)\end{array}$ & $\begin{array}{c}\text { Luas } \\
\left(\mathbf{k m}^{2}\right)\end{array}$ & \multicolumn{1}{c}{$\begin{array}{c}\text { Luas } \\
\left(\mathbf{k m}^{2}\right)\end{array}$} & $\begin{array}{c}\text { Luas } \\
\left(\mathbf{k m}^{2}\right)\end{array}$ & $\begin{array}{c}\text { Luas } \\
\left(\mathbf{k m}^{2}\right)\end{array}$ & $\begin{array}{c}\text { Luas } \\
\left(\mathbf{k m}^{2}\right)\end{array}$ \\
\cline { 2 - 7 } & \multicolumn{1}{c}{ tahun } & 5 tahun & 10 tahun & 20 tahun & 50 tahun & 100 tahun \\
\hline Hutan & - & 0.0478 & 0.1221 & 0.157 & 0.1635 & 0.1715 \\
Kebun & 6.9221 & 10.7831 & 17.3787 & 18.637 & 19.8058 & 20.3175 \\
Perairan Darat & 4.539 & 0.3091 & 0.32 & 0.444 & 0.4472 & 0.4684 \\
Permukiman & 9.9151 & 14.6247 & 23.348 & 26.417 & 28.1822 & 28.9304 \\
Persawahan & 103.8686 & 141.9643 & 181.6051 & 191.653 & 194.4434 & 196.9052 \\
Pertanian Tanah Kering & & & & & & \\
Semusim & 1.2309 & 1.4992 & 1.8469 & 1.974 & 1.9742 & 2.0023 \\
\hline Total & $\mathbf{1 2 6 . 4 7 5 7}$ & $\mathbf{1 6 9 . 2 2 8 2}$ & $\mathbf{2 2 5 . 6 9 0 9}$ & $\mathbf{2 4 0 . 6 2 1 8}$ & $\mathbf{2 4 6 . 3 6 9 6}$ & $\mathbf{2 5 0 . 3 2 6 1}$ \\
\hline Sumber: Hasil Perhitungan & $(2016)$ & & & & &
\end{tabular}

Tata guna lahan yang terdampak oleh genangan banjir hasil simulai debit berbagai kala ulang diperlihatkan oleh Tabel 6. Daerah yang paling luas terdampak genangan banjir adalah pesawahan dan pemukiman. Dua jenis tata guna lahan ini merupakan tempat kehidupan manusia dan mempunyai nilai ekonomi tinggi. Sehingga dampak yang akan terjadi sangat besar untuk kehidupan manusia.
Dari Tabel 6 dapat dilihat bahwa meskipun luasan banjir di Kecamatan Bojonegoro bukan yang paling luas, tetapi genangannya memberikan dampak pada wilayah pemukiman yang paling besar, yaitu $1,2259 \mathrm{~km}^{2}, 3,1547$ $\mathrm{km}^{2}, 6,3524 \mathrm{~km}^{2}, 7,0198 \mathrm{~km}^{2}, 7,7796 \mathrm{~km}^{2}$ dan $7,9113 \mathrm{~km}^{2}$ untuk masing-masing kala ulang 2, $5,10,20,50,100$ tahun. 


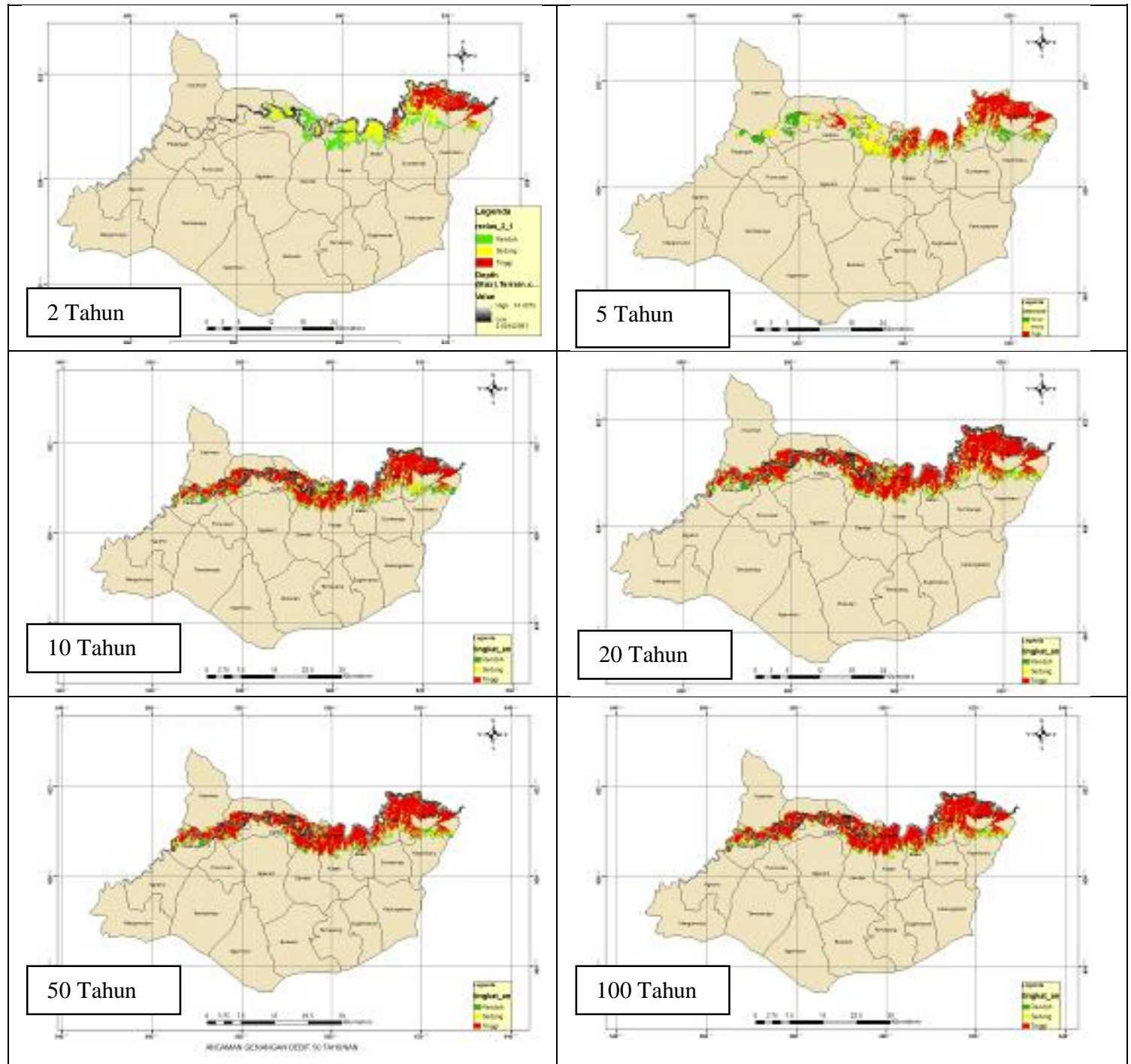

Gambar 10. Sebaran tingkat ancaman banjir berdasarkan kedalaman

Sumber: Hasil Analisis (2016)

\section{KESIMPULAN}

Kesimpulan yang dapat diambil dari hasil perhitungan, analisa dan pembahasan tesis ini adalah sebagai berikut:

Luas daerah genangan banjir hasil simulasi banjir kejadian Desember 2007 adalah $359,38 \mathrm{~km}^{2}$. Rasio perbandingan langsung antara luasan genangan hasil simulasi dan pengukuran sebesar 0,87 dengan presentase luasan yang sama antara model dan pengukuran adalah sebesar 77,3\%. Nilai kesesuaian yang didapatkan masuk kategori bagus sebesar 0,71 berdasarkan metode Bates, dkk, tetapi apabila menggunakan metode $\mathrm{Di}$ Baldassare didapatkan nilai kesesuainnya 0,56.

Luas genangan hasil simulasi pada masing-masing kala ulang di Kabupaten Bojonegoro adalah $250,3260 \mathrm{~km}^{2}$, untuk debit dengan kala ulang 100 tahun. Berturut-turut luas genangan simulasi di Kabupuaten Bojonegoro untuk debit kala ulang 50, 20, 10, 5, 2 tahun adalah 246,3696 $\mathrm{km}^{2}, 240,6218$ $\mathrm{km}^{2}, \quad 225,6909 \mathrm{~km}^{2}, 169,2282 \mathrm{~km}^{2}$, dan $126,4757 \mathrm{~km}^{2}$.

Wilayah yang tergenang paling luas pada kala ulang 2 tahun adalah kecamatan Baureno dengan luas $35,159 \mathrm{~km}^{2}$ atau sebanyak 52,97\% dari luas Kecamatan Baureno. Pada kala ulang 5 dan 10 tahun, Kecamatan Baureno juga merupakan daerah yang paling banyak mendapatkan desa terdampak banjir yang meliputi 58,73\% dan 64,82\% dari luas Kecamatan Bureno. Kecamatan Kanor merupakan daerah yang paling terdampak untuk kala ulang 20, 50 dan 100 tahun dengan luas 44,889 $\mathrm{km}^{2}(75,09 \%)$, $44,809 \mathrm{~km}^{2}(74,96 \%)$ dan $45,244 \mathrm{~km}^{2}$ 
(75,68\%), pada 24 desa. Prosentase luas wilayah yang paling besar terdampak genangan banjir adalah Kecamatan Bojonegoro sebesar 77,60 \% pada kala ulang 10 tahun. Diikuti oleh Kecamatan Kanor dimana 69,75\% wilayahnya terdampak genangan dan kecamatan Baureno $64,82 \%$ wilayahnya terkena genangan banjir.

Kecamatan yang memiliki tingkat ancaman tinggi pada debit dengan kala ulang 10 tahun adalah Kecamatan Balen, Baureno, Bojonegoro, Dander, Kalitidu, Kanor, Kapas, Kasiman, Malo dan Trucuk.

Luas pemukiman yang paling tinggi terdampak genangan banjir pada kala ulang 10 tahun adalah di Kecamatan Bojonegoro, 6,35 $\mathrm{km}^{2}$ atau setara dengan $69,7 \%$ dari luas permukiman yang ada. Dengan kepadatan penduduk didaerah pemukiman $9112 \mathrm{jiwa} / \mathrm{km}^{2}$, maka diperkirakan sekitar 57.885 orang akan terdampak banjir. Dampak genangan banjir untuk seluruh Kabupaten Bojonegoro diperkirakan sekitar 160.542 jiwa terancam banjir.

\section{DAFTAR PUSTAKA}

Alho, P. Hyyppä, H. dan Hyyppä, J. 2008. Consequence of DTM Precision for Flood Hazard Mapping: A Case Study in SW Finland. Nordic Journal of Surveying and Real Estate Research 6:1 (2009) hal. 21-39.

Ali , A. Md, Solomatine, D. P. and Di Baldassarre, G. Assessing the impact of different sources of topographic data on 1-D hydraulic modelling of floods. Hydrol. Earth Syst. Sci., 19, 631-643, 2015 www.hydrol-earthsyst-sci.net/19/631/2015/

Bates, P.D., De Roo, A.P.J. 2000. A simple raster-based model for flood inundation simulation. Journal of Hydrology 236 (2000) 54-77.

Badan Nasional Penanggulangan Bencana. BNPB. 2012. Peraturan Kepala Badan Nasional Penganggulangan Bencana (BNPB) No.2 Tahun 2012: Pedoman Umum Pengkajian Risiko Bencana, Kantor BNPB, Jakarta.

Badan Nasional Penanggulangan Bencana. Badan Nasional Penanggulangan Bencana (BNPB). 2016. Data Informasi Bencana Indonesia. http://dibi.bnpb-.go.id. Diakses 2 Desember 2016.

De Silva, M. M. G. T., Weerakoon, S. B., Herath, Srikantha, Ratnayake, U. R.. 2012. Event Based Flood Modeling In Lower Kelani Basin. SAITM Research Symposium on Engineering Advancements (SAITM - RSEA 2012)

Di Baldassarre, G. Schumann, G. Bates, P. D. 2009. A technique for the calibration of hydraulic models using uncertain satellite observations of flood extent. Journal of Hydrology 367. hal. 276282.

European Exchange Circle On Flood Mapping (EXIMAP). 2007. Handbook on good practices for flood mapping in Europe.

Goel, N.K., Than, Htay Htay., Arya, D.S. 2005. Flood Hazard Mapping In The Lower Part Of Chindwin River Basin, Myanmar. International conference on innovation advances and implementation of flood forecasting technology. Troms $\emptyset$, Norway.

Mathevet, T. Michel, C. Andreassian V. Perrin C. 2006. A Bounded Version of the Nas-Sutcliffe Criterion for Better Model Assessment on Large Sets of Basins. Large Sample Basin Experiments for Hydrological Model Parameterization: Results of the Model Parameter Experiment-MOPEX. IAHS Publ. 307, 2006.

Sarhadi, Ali. Soltani, Saeed. Modarres, Reza. Probabilistic flood inundation mapping of ungauged rivers: Linking GIS techniques and frequency analysis. Journal of Hydrology 458-459 (2012) 68-86

Silva GD. (2016). Event Based Flood Inundation Mapping Under the Impact of Climate Change: A Case Study in Lower Kelani River Basin, Sri Lanka. Hydrol Current Res 7: 228. doi:10.4172/2157-7587.1000228

St. Johns River Water Management District (SJRWMD). 2016. Chapter 3: Watershed Hydrology Appendix 3.D: Evaluation Of Model Uncertainty. http://www.sjrwmd.com/technicalrepo rts/pdfs/TP/SJ2012-1_Appendix03D.pdf. diakses 21 Agustus 2016. 